\title{
The fitness of middle age to the elderly based on body mass index and age in the new normal era
}

\author{
Muhammad Akbar Juliansyah* ${ }^{\mathbb{D}}$, FX Sugiyanto ${ }^{\mathbb{D}}$, I Putu Agus Dharma Hita \\ Universitas Negeri Yogyakarta, Indonesia
}

Received: 03 February 2021; Accepted 23 May 2021; Published 01 August 2021

Ed 2021; 6(2): 254-262

\begin{abstract}
Decrease in physical fitness occurs after the age of 30 years and factors that affect physical fitness include age, gender, BMI, waist circumference, hypertension, and diabetes mellitus. This study aims to determine the physical fitness of middle-aged to elderly people between 45-74 years based on BMI and age. This research is a descriptive study with quantitative methods. The sample of this research is men who are active in badminton activities in Rejang Lebong Regency, which are classified as middle age to elderly people who are taken by purposive sampling. The data collection technique used the BMI test and fitness test. The results show that 1) The average BMI value in middle age to the elderly is $25.47 \mathrm{~kg} / \mathrm{m} 2$, in the category of light fat. The average value of physical fitness in middle age to the elderly is 33.39 , with a very poor category. 2) $26.3 \%$ of people have normal nutritional status, $50 \%$ of people have mild nutritional status and $23.7 \%$ of people have severe nutritional status. 3) $84.2 \%$ of people have very poor fitness category, $10.5 \%$ of people have poor physical fitness category and $5.3 \%$ of people have moderate physical fitness category. So it can be concluded that middle-aged to elderly people with high BMI have less physical fitness and the more middle-aged to elderly people have less physical fitness.
\end{abstract}

Keywords: Body Mass Index (BMI); physical fitness; elderly; middle age

https://doi.org/10.25299/sportarea.2021.vol6(2).6362

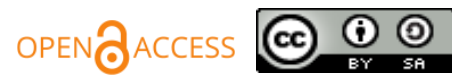

Copyright @ 2021 Muhammad Akbar Juliansyah, FX Sugiyanto, I Putu Agus Dharma Hita

Corresponding author: Muhammad Akbar Juliansyah, Postgraduate Program of Sport Science, Universitas Negeri Yogyakarta, Yogyakarta, Indonesia

Email: akbarjuliansy@gmail.com

How to Cite: Juliansyah, M. A., Sugiyanto, F., \& Hita, I. P. A. (2021). The fitness of middle age to the elderly based on body mass index and age in the new normal era. Journal Sport Area, 6(2), 254-262. https://doi.org/10.25299/sportarea.2021.vol6(2).6362

\section{INTRODUCTION}

Health becomes a very expensive thing when someone is sick. Health can be defined as a state of physical, mental, social, and spiritual health (Bryantara, 2016). It is said to be in a state of physical health if a person is fit, physical fitness is related to a person's physical abilities in daily activities effectively and efficiently (Yusuf, 2018). Physical fitness is related to physical conditions in carrying out daily activities properly without significant fatigue and still having energy reserves remaining (Utari et al., 2015). Fitness is very important as one of the supporters of one's daily activities, so someone who has good fitness can go about their daily lives without significant fatigue. The results of a study conducted in West Denpasar on 96 elderly, concluded that the elderly who have good fitness are more in the elderly who work than those who do not work (Tripayana, 2020). This means that when a person does a lot of physical activity such as working all day, when he returns home he still has energy left to do other things such as doing workouts at home. Doing a lot of physical activity, the body indirectly has good fitness when compared to someone who is not physically active or just sits all day. 
Physical fitness is important for a person's life to carry out daily activities. When they are children most of them can not stay still and want to try new physical activities, such as running, jumping, climbing nonstop. This indicates that children have a lot of physical activity so that they sometimes do not feel tired, in contrast to the physical activities done by adults. Also supported by the research of Chiesa et al., (2020), the findings strengthen that by starting to maintain physical fitness at a young age, you can reduce the risk of obesity and the benefits of physical fitness in old age. Therefore, the elderly must be aware of and begin to maintain physical fitness at a young age.

Previous research concluded that there is a strong relationship between physical activity and fitness level and between BMI and fitness level also has a strong relationship (Alamsyah et al., 2017). The higher the BMI, the lower the physical fitness (Prasetio et al., 2018). BMI is a simple technique to easily find out a person's nutritional status. It only takes a calculation between weight divided by height. Efforts to maintain and improve physical fitness must still be carried out in a disciplined manner and in fact it is also part of a lifestyle (Sulistiono, 2014). Maintaining physical fitness has many factors, one of which is a healthy lifestyle and physical activity, then carried out in a sustainable manner. Factors such as gender, age, and BMI also affect a person's level of physical fitness (Oktriani et al., 2020), and the role of the family is needed in knowing information about nutritional status and fitness (Zelvya, 2014).

Indonesia has changed completely because it is facing and fighting the spread of a virus, this virus is called Corona Virus Disease (COVID-19). The number of positive Covid-19 patients is increasing day by day and most of the patients are elderly (elderly). dr. Achmad Yurianto, who is appointed as the government's spokesman for the Covid-19 case, said that most of the patients who died occurred in the 4180 year old range (Kementerian Kesehatan, 2020). WHO states that the elderly are the group most vulnerable to COVID-19. The elderly population in Indonesia continues to increase because in the health sector it continues to progress with decreasing mortality rates and increasing life expectancy. In five decades, the elderly in Indonesia have doubled to 9.92 percent or 26 million. The elderly in Indonesia are in the aging population structure with the percentage of elderly from 2020 reaching more than 10 percent and will even reach one-fifth of Indonesia's population (BPS, 2020a). The elderly or elderly population in Indonesia is predicted to continue to increase 1 higher1 than the elderly population in the world, after 2100 (Kementerian Kesehatan, 2016). In the regulation 1 of the Minister of Social Affairs 1 of the Republic of Indonesia number 191 of 2012 that an elderly person is someone who has 1 reached the age of 60 (sixty) years and above (Kementerian Sosial RI, 2012). According to WHO, it is called middle age, those aged 4559 years, called old or elderly in the age range of 60-74 years, called elderly people aged 75-90 years, and very old age aged 90 years and above.

Throughout 2020, Indonesia faces new challenges. During the 2020 COVID-19 pandemic, the elderly face challenges that must be faced, because the elderly are the age at risk and the most vulnerable to COVID-19. This is certainly a concern for the elderly. The elderly are most vulnerable to COVID-19 due to weakened immune function (BPS, 2020a). Everyone will experience a decrease in the body's functional capacity sooner or later. The older you get, the less functional your body will be. When it comes to age, everyone will experience a slow decline in body cell functions. Sukirno (2014) also explained that over 30 years $0.8-1 \%$ per year all cells in the body will experience functional decline. Humans with increasing age and accompanied by a decrease in physical condition, body organs, and functions of the brain are said to be elderly (Putra \& Suharjana, 2018). The body's immune system will continue to decline slowly with unexpected symptoms as a person ages, then it will increase the risk of diseases including chronic and degenerative diseases (Aspinall, 2005).

In this study, the middle aged to the elderly in Rejang Lebong only exercised badminton within 1 to 2 hours with a frequency of $1 \mathrm{a}$ week, it means that in a week the middle aged to the elderly only exercised 60 to 120 minutes a week, where the researchers agree on sports for fitness at least -the minimum is 150 minutes a week (Bull et al., 2020). In this study there is also no comparative data between before and after the new normal era, but the researchers only want to know the physical fitness of the middle-aged to the elderly when viewed from body mass index and age. 
Given the risk in the elderly who are the most vulnerable to COVID-19 and the importance of physical fitness in the elderly to improve the body's immune system through physical activity and control BMI, the authors aim to find out fitness in middle-aged to elderly men (45-74) years old who play badminton in Rejang Lebong Regency based on BMI and age.

\section{METHODS}

Based on this objective, this is a quantitative descriptive study in which the authors want to know the fitness of the middle-aged to the elderly who play badminton in Rejang Lebong Regency based on BMI and age. This research is a descriptive type of research, namely research to describe a particular event or phenomenon (Maksum, 2012). The author's sample selection uses purposive sampling technique (Darmadi, 2011). Rejang Lebong Regency itself is located in Bengkulu Province, the number of elderly people in Bengkulu Province reaches 234,000 people (BPS, 2020b). The population in this study does not have accurate data, because the number of middle-aged to elderly people who are active in playing badminton in Rejang Lebong Regency is not recorded. The authors only have criteria for sampling and ask for permission when getting samples that fall within the research criteria. The criteria for this study are men who are only 45-74 years old (middle to elderly). Physical activity is active in badminton and focuses on Rejang Lebong Regency. In this study 38 samples are obtained with 33 middle-aged people (45-59) and 5 elderly people (60-74). The authors obtain 38 samples due to several obstacles, namely some middle-aged to elderly people refuse to be samples for several reasons. Such as fear of knee injury relapse when taking a fitness test, feeling unable to do it before being tested and feeling that they don't need to know their fitness. Data collection starts from calculating body mass index (BMI) (P2PTM Kemenkes RI, 2019) with a calculation based on 1 weight divided by 1 body height, with the formula:

\section{$\mathrm{IMT}=$ Weight $(\mathrm{kg})$ \\ Height $\left(\mathrm{m}^{2}\right)$}

Table 1. Body Category based on IMT

\begin{tabular}{cccc} 
No & & Category & IMT \\
\hline 1 & Thin & Less weight level heavy & $<17,0$ \\
& & Less weight level light & $17,0-18,4$ \\
2 & Normal & Normal & $18.5-25,0$ \\
& & Over weight level light & $25,1-27,0$ \\
3 & Fat & Over weight level heavy & $>27,0$ \\
\hline
\end{tabular}

(P2PTM Kemenkes RI, 2019)

Then the fitness test data are collected using the Harvard step test instrument developed by Lucian Brouha in 1943, the height of the Harvard step test bench is for 20 inches with a metronome rhythm of 120 times per minute or with a volume of 30 steps per minute, for 5 minutes or until no able to do it again. Samples are given time for static and dynamic heating. The sample is given time to try to get up and down the bench. Up and down the bench the left foot goes up to the bench followed by the right foot, and down the left foot first followed by the right foot or vice versa. The sample stands in front of the bench then when the cue starts, the sample goes up and down the bench by following the rhythm of the metronome $120 \mathrm{x}$ per minute until it can't do up and down the bench or for 5 minutes. After the sample has finished or is unable to continue, the sample sits down and the pulse rate will be calculated after resting 1 minute, 2 minutes and 3 minutes after the test for 30 seconds (Brouha, 1943). Then the calculation will be carried out with the following formula:

Training Duration (in second) x 100

$2 \mathrm{x}$ Number of Pulses in Recovery 
Table 2. Category of Harvard Step Test

\begin{tabular}{ccc}
\hline No & Category & Range \\
\hline 1 & Very less & Under 55 \\
2 & Less & $56-64$ \\
3 & Enough & $65-79$ \\
4 & Good & $80-89$ \\
5 & Very Good & 90 \\
\hline
\end{tabular}

(Brouha, 1943)

After the BMI and fitness data are obtained, the data will be processed using SPSS for Windows 22.

\section{RESULTS AND DISCUSSIONS}

BMI data retrieval uses the calculation of height and weight. Physical fitness test uses Harvard step test. Based on the data obtained and analyzed uses SPSS, the following are the results of the analysis contained in the following table.

Table 3. Age Average

\begin{tabular}{cccccc}
\hline & N & Min. & Max. & Mean & Std. Deviation \\
\hline Age & 38 & 45 & 63 & 51.2 & 5.272 \\
Amount & 38 & & & & \\
\hline
\end{tabular}

Based on the results in table 3, it can be seen that the number of samples was 38 people, the average age of the sample was 51 years, with a min age of 45 and a max age of 63 years.

Table 4. Average of IMT and Physical Fitness

\begin{tabular}{cccccc}
\hline & N & Mean & Std. Deviation & Min. & Max. \\
\hline IMT $\left(\mathrm{kg} / \mathrm{m}^{2}\right)$ & 38 & 25.47 & 3.9626 & 19.0 & 36.1 \\
Physical Fitness & 38 & 33.39 & 18.371 & 10 & 78 \\
\hline
\end{tabular}

Based on the results in table 4, the average BMI value in the middle age to the elderly is $25.47 \mathrm{~kg} / \mathrm{m} 2$, which can be categorized as mild fat with a min value of 19 and a max value of 36.1. The average value of physical fitness in the middle age to the elderly is 33.39 , can be categorized as less than once, with a min value of 10 and a max value of 78 .

Table 5. Data of Body Mass Index

\begin{tabular}{cccccc}
\hline & & Frequency & Percent & Valid Percent & Cumulative Percent \\
\hline \multirow{4}{*}{ Valid } & Normal & 10 & 26.3 & 26.3 & 26.3 \\
& Fat level light & 19 & 50.0 & 50.0 & 76.3 \\
& Fat level heavy & 9 & 23.7 & 23.7 & 100.0 \\
\hline & Amount & 38 & 100.0 & 100.0 & \\
\hline
\end{tabular}

Based on the results of the data in table 5 , that 10 or $26.3 \%$ of people have normal nutritional status, 19 or $50 \%$ of people have mild nutritional status and 9 or $23.7 \%$ of people have severe nutritional status.

Table 6. Data of Physical Fitness

\begin{tabular}{cccccc}
\hline & & Frequency & Percent & Valid Percent & Cumulative Percent \\
\hline \multirow{4}{*}{ Valid } & Very Less & 32 & 84.2 & 84.2 & 84.2 \\
& Less & 4 & 10.5 & 10.5 & 94.7 \\
& Enough & 2 & 5.3 & 5.3 & 100.0 \\
& Amount & 38 & 100.0 & 100.0 & \\
\hline
\end{tabular}

Based on the results of the data in table 6 , that 32 or $84.2 \%$ of people have a very poor fitness category, 4 or $10.5 \%$ of people have a poor physical fitness category and 2 or $5.3 \%$ people have a sufficient physical fitness category. 
Table 7. Data of Physical Fitness based on IMT

\begin{tabular}{ccccccc}
\hline & & Very Less & Less & Enough & Amount \\
\hline \multirow{3}{*}{ Nutrition Status } & Normal & 6 & 2 & 2 & 10 & 19 \\
& & Fat level light & 17 & 2 & 0 & 9 \\
& Fat level heavy & 9 & 0 & 0 & 38 \\
\hline
\end{tabular}

Based on the results of the data in table 7 with normal nutritional status there are 6 people with a very low level of fitness, 2 people with a low level of fitness and 2 people with a sufficient level of fitness. The nutritional status of mild obesity is 17 people with a very low level of fitness, 2 people with a low level of fitness and the nutritional status of severe obesity is 9 people with a very low level of fitness.

Table 8. Data of Fitness based on Age

\begin{tabular}{ccccccc}
\hline & & & Very Less & Less & Enough & Amount \\
\hline \multirow{2}{*}{ Age } & & Middle-age & 27 & 4 & 2 & 33 \\
& & Elderly & 5 & 0 & 0 & 5 \\
\hline & Amount & & 32 & 4 & 2 & 38 \\
\hline
\end{tabular}

Based on the results of the data in table 8, with middle age there are 27 people with a very low level of fitness, 4 people with a low level of fitness and 2 people with a moderate level of fitness category. At the age of the elderly there are 5 people with a very low level of fitness.

Based on table 7, physical fitness in the less category is dominated by light weight BMI status and followed by heavy fat BMI status. This means that the higher the BMI status and the worse the physical fitness. In normal BMI status, fit 1 times 1 times higher than in obese BMI status. In obese BMI status, the level of physical fitness category is less (Prasetio et al., 2018). Supported by research on 75 students, that the percentage of body fat and BMI has an inverse correlation with the value of VO2 max and flexibility. Adding gender will strengthen the correlation with BMI, with the exception of body fat percentage and flexibility. Then it is recommended to use body fat percentage as a predictor for VO2 max, compared to using BMI (Dewi et al., 2015).

Research conducts on online motorcycle taxi drivers shows that there is a relationship between BMI and the level of physical fitness in motorcycle taxi drivers (Pratama \& Sutiari, 2020). Similarly, research conducts on PON athletes, based on the results of chi square $p=0.007$ and shows that there is a relationship between BMI and physical fitness level (Budiawan \& Susila, 2020). Research conducts at football clubs and shows that at the age of 18 to 35 years, those with normal BMI have a good level of fitness and at the age of 35 to 45 years, those with obese BMI status have less fitness. Then this study concludes that between age and BMI there is a strong relationship with physical fitness levels (Bryantara, 2016). Research conducts on 83 medical students who are mostly busy in academics and pay less attention to physical fitness, based on data, most students have a normal BMI and most are 22 years old, but the characteristics of physical activity in students are very low and have poor physical fitness. Then the p-value is 0.007 , and it is concluded that there is a relationship between BMI and physical fitness kebugaran (Syauqy, 2017).

Based on table 8, almost all middle-aged to elderly are included in the category of very poor physical fitness, although in middle age there are still some who have sufficient fitness. This means that the older the age, the lower the level of physical fitness. It is supported by research conducted on the elderly, that the elderly who maintain physical fitness can slow down the degenerative process, but the fact is that the elderly experience a lot of physical decline due to not maintaining physical fitness and the results show that the level of physical fitness of the elderly has a relationship with age, marital status, physical activity. and lifestyle. This means that when the elderly do sports or physical activities that are appropriate for their age and live a healthy lifestyle, the physical fitness of the elderly is also better (Wijaya et al., 2020).

Research conducts Nurfadli et al., (2015) on construction workers aged 20-30 years whose physical fitness level is classified as low but has a normal BMI category, so in this study it is concluded that there is no relationship between BMI and physical fitness, because the workers are still young and have a normal BMI. Research conducts on high school students, the findings shows that between BMI and physical fitness 
level does not have a significant relationship because most students' BMI is in the normal category, but between physical activity and physical fitness level has a significant relationship. In this study, one of the factors that affect the level of physical fitness is physical activity (Satin et al., 2021). This means that it can be concluded that physical fitness has factors that influence it, such as age, physical activity and BMI. Supported by research conducted (Oktriani et al., 2020) that based on the results of the probability value of 0.012 , it shows that between age, gender and BMI has a relationship with the level of physical fitness of the elderly. Plus research from Yusri et al., (2020) that the factors that affect physical fitness are age, gender, BMI, waist circumference, hypertension, and diabetes mellitus. This will definitely happen because at the age of over 30 years, $0.8-1 \%$ per year, all cells in the body will experience a functional decline (Sukirno, 2014).

The new findings that researchers can get are at middle age there are 2 people who have a moderate level of fitness. This proves that the elderly has the opportunity to have good fitness if it is supported by good physical activity. It is also supported that the elderly who show a good level of fitness are supported by physical activity, the factors causing the elderly to be physically active are the background of the location of residence, gender, type of physical activity, and also the social environment (Wardhana \& Anwar, 2020). This means that if you are from middle age or before you reach the age of old, if you are diligent in physical activity, it will affect the age level that will come. Research conducts on Indonesian Migrant Workers, shows that the average total energy expenditure of workers is in the low category and based on BMI the average has light physical activity that affects the body's immune system. Exercising has many benefits, not only BMI but also has benefits in maintaining and improving the body's immune system by doing physical activity, exercising, and getting enough rest (Hita et al., 2020). Coupled with research on the elderly that BMI will increase with age and physical fitness worsens in the elderly group. Being more active by increasing physical activity has benefits for the elderly with regard to BMI (Tuna et al., 2009).

Doing physical exercise affects the fitness of the elderly. There are various exercises such as gymnastics, pilates, jogging, etc. according to the abilities of the elderly (Anuar et al., 2021). Maintain fitness through aerobic exercise while still paying attention to FITT (frequency, intensity, time, and tempo) (Syahruddin, 2020). Physical activities such as walking, cycling can be done according to the abilities and environmental conditions of the elderly (Mubarroh et al., 2021). In 2020 WHO issued an article compiled by several authors regarding guidelines on physical activity, in the study recommending for children to adolescents physical activity at least an average of 60 minutes a day with high intensity, for adults aged 18 to 64 years of activity. 150-300 minutes of physical activity in one week of moderate intensity or 75-150 minutes of high intensity or a combination of both, and for the elderly with age $>64$ years of physical activity 150 minutes a week of moderate intensity or 75 minutes of high intensity or a combination of both (Bull et al., 2020).

\section{CONCLUSION}

Based on the results of the analysis of fitness research between the middle-aged and the elderly who exercise badminton based on BMI and age in Rejang Lebong Regency, it can be concluded that the middleaged to the elderly have a BMI in the category of light fat and physical fitness in the category of very little which can affect the body's immunity, half-life old age to the elderly with a high BMI have a very low level of physical fitness. The more middle age to the elderly, the level of physical fitness is very less but by maintaining good fitness at a young age, the elderly has the opportunity to have good fitness in old age. Based on the results of existing studies, physical fitness has factors that influence it, namely age, gender, BMI, waist circumference, hypertension, and diabetes mellitus.

This study has shortcomings due to limited time and funds from the author. The total population in the study does not have data. The sample is still small because it is only done on middle-aged men to the elderly who actively play badminton in Rejang Lebong district. It is recommended for further researchers to pay more attention to the population so that the required number of samples is more accurate. Adding related variables such as gender so that there is comparative data between male and female elderly. The author suggests that the middle-aged to the elderly are expected to regulate BMI status. Maintain physical fitness 
by carrying out physical activities as recommended by World Health Organization in order to increase body immunity and avoid COVID-19 and other viruses while still observing health protocols.

\section{REFERENCES}

Alamsyah, D. A. N., Hestiningsih, R., \& Saraswati, L. D. (2017). Faktor-Faktor yang Berhubungan dengan Kebugaran Jasmani Pada Remaja Siswa Kelas XI SMK Negeri 11 Semarang. Jurnal Kesehatan Masyarakat, 5(3), 77-86.

Anuar, R., Imani, D. R., Nadhir, S., \& Norlinta, O. (2021). Pengaruh Latihan Fisik Terhadap Kebugaran Lansia Dalam Masa Pandemi Covid-19. Narrative Review. 2(2), 95-106. https://doi.org/10.23917/fisiomu.v2i2.13978

Aspinall, R. (2005). Ageing and the immune system in vivo: Commentary on the 16th session of British Society for Immunology Annual Congress, Harrogate, December 2004. Immunity and Ageing, 2(December 2004). https://doi.org/10.1186/1742-4933-2-5

BPS. (2020a). Statistik Penduduk Lanjut Usia. Badan Pusat Statistik. www.bps.go.id

BPS. (2020b). Statistik Penduduk Lanjut Usia Provinsi Bengkulu. Badan Pusat Statistik. www.bps.go.id

Brouha, L. (1943). The step test: A simple method of measuring physical fitness for muscular work in young men. Research Quarterly of the American Association for Health, Physical Education and Recreation, 14(1), 31-37. https://doi.org/10.1080/10671188.1943.10621204

Bryantara, O. F. (2016). Faktor yang berhubungan dengan kebugaran jasmani vo2maks atlet sepakbola. Jurnal Berkala Epidemiologi, 4(2), 237-249. https://doi.org/10.20473/jbe.v4i2.2016.237

Budiawan, M., \& Susila, I. K. (2020). Hubungan antara indeks massa tubuh (IMT) dengan tingkat kebugaran jasmani atlet PON Bali tahun 2020. Seminar Nasional Riset Inovatif 2020, 7(1), 336-340.

Bull, F., Saad Al-Ansari, S., Biddle, S., Borodulin, K., Buman, M., Cardon, G., Carty, C., Chaput, J.-P., Chastin, S., Chou, R., Dempsey, P., DiPietro, L., Ekelund, U., Firth, J., Friedenreich, C., Garcia, L., Gichu, M., Jago, R., Katzmarzyk, P., ... Willumsen, J. (2020). World Health Organization 2020 Guidelines on Physical Activity and Sedentary Behaviour. British Journal of Sports Medicine, 14511462. https://doi.org/10.1136/bjsports-2020-102955

Chiesa, S. T., Charakida, M., \& Deanfield, J. E. (2020). Adolescent health and future cardiovascular disability: It's never too early to think about prevention. European Heart Journal, 41(15), 1511-1513. https://doi.org/10.1093/eurheartj/ehz869

Darmadi, H. (2011). Metode Penelitian Pendidikan. Bandung: Alfabeta.

Dewi, M., Kustiyah, L., \& Kuswari, M. (2015). Percent Fat Mass and Body Mass Index As Cardiorespiratory Fitness Predictors in Young Adults. Jurnal Gizi dan Pangan, 10(3), 179-184. https://doi.org/10.25182/jgp.2015.10.3.\%p 
Hita, I. P. A. D., Kushartanti, B. M. W., \& Nanda, F. A. (2020). Physical Activity, Nutritional Status, Basal Metabolic Rate, and Total Energy Expenditure of Indonesia Migrant Workers during Covid-19 Pandemic. Jurnal Pendidikan Jasmani dan Olahraga, 5(2), 122-128. https://doi.org/10.17509/jpjo.v5i2.26791

Kementerian Kesehatan, R. I. (2016). Situasi Lanjut Usia (Lansia) di Indonesia. Lansia Sehat Lansia Aktif dan Produktif. Pusat Data dan Informasi.

Kementerian Kesehatan, R. I. (2020). Pasien positif corona meninggal dominan lansia. 8-9. www.depkes.go.id

Kementerian Sosial RI. (2012). Peraturan Menteri Sosial Republik Indonesia nomor 19 tahun 2012 Tentang Pedoman Pelayanan Sosial Lanjut Usia.

Mubarroh, N. R., Susanto, I. H., \& Mustar, Y. S. (2021). Aktivitas fisik dan aspek kekhawatiran lansia pada masa pandemi Covid-19. Altius: Jurnal Ilmu Olahraga dan Kesehatan,10(1), 97-111. http://dx.doi.org/10.36706/altius.v10i1.14140

Maksum, A. (2012). Metodologi Penelitian dalam Olahraga. Surabaya: Unesa University Press.

Nurfadli, R., Jayanti, S., \& Suroto, S. (2015). Hubungan Indeks Massa Tubuh dan Frekuensi Olahraga Terhadap Kebugaran Jasmani Pekerja Konstruksi di PT. (Persero) TBK Proyek Apartemen Pinnacle Semarang Pinnacle Semarang. Jurnal Kesehatan Masyarakat, 3(1), 445-453.

Oktriani, S., Kusmaedi, N., Daniel Ray, H. R., \& Setiawan, A. (2020). Perbedaan Jenis Kelamin, Usia, dan Body Mass Index (BMI) Hubungannya dengan Kebugaran Jasmani Lanjut Usia. Jurnal Terapan Ilmu Keolahragaan, 5(1), 28-40. https://doi.org/10.17509/jtikor.v5i1.24895

P2PTM Kemenkes RI. (2019). Tabel Batas Ambang Indeks Massa Tubuh (IMT). Kementerian Kesehatan RI. http://www.p2ptm.kemkes.go.id/infographic/tabel-batas-ambang-indeks-massa-tubuh-imt

Prasetio, E., Sutisyana, A., \& Ilahi, B. R. (2018). Tingkat Kebugaran Jasmani Berdasarkan Indeks Massa Tubuh Pada Siswa SMP Negeri 29 Bengkulu Utara. Kinestetik, 2(2), 166-172. https://doi.org/10.33369/jk.v2i2.8738

Pratama, Y., \& Sutiari, N. K. (2020). Hubungan Status Gizi Dengan Tingkat Kebugaran Jasmani Pada Driver Ojek Online. Jurnal Gizi Prima (Frime Nutrition Journal), 5(1), 65-74. https://doi.org/10.32807/jgp.v5i1.177

Putra, E. F., \& Suharjana, S. (2018). Model senam lansia untuk kebugaran jasmani dan fungsi otak Modelling the elder people gymnastics for physical fitness and cognitive function. Jurnal Keolahragaan, 6(2), 120-129. https://doi.org/10.21831/jk.v0i0.20626

Satin, P. M., Yohanis M. Mandosir, Irmanto, M., Susanto, I. H., \& Kristanto, B. (2021). Hubungan Antara Status Gizi Dan Aktivitas Fisik Dengan Tingkat Kebugaran Jasmani Siswa. Jurnal Pendidikan Olahraga dan Kesehatan, 4(2), 516-521.

Sukirno. (2014). Kesehatan Olahraga, Doping dan Kesegaran Jasmani. Sriwajaya: Unsri Press. 
Sulistiono, A. A. (2014). Kebugaran jasmani siswa pendidikan dasar dan menengah di Jawa Barat. Jurnal Pendidikan dan Kebudayaan, 20(2), 223-233. https://doi.org/10.24832/jpnk.v20i2.140

Syahruddin. (2020). Kebugaran Jasmani Bagi Lansia Saat Pandemi Covid-19. JUARA : Jurnal Olahraga, 5(2), 232-239. https://doi.org/10.33222/juara.v5i2.943

Syauqy, A. (2017). Hubungan indeks massa tubuh dengan kebugaran jasmani mahasiswa prodi kedokteran UNJA. Jambi Medical Journal: Jurnal Kedokteran dan Kesehatan, 5(1), 87-93. https://doi.org/10.22437/jmj.v5i1.4506

Tripayana, I. N. (2020). Kebugaran Jasmani Lansia di Tahun 2019. Kampurui Jurnal Kesehatan Masyarakat, 2(1), 1-6.

Tuna, D. H., Ozcan Edeer, A., Malkoc, M., \& Aksakoglu, G. (2009). Effect of age and physical activity level on functional fitness in older adults. European Review of Aging and Physical Activity, 6(2), 99106. https://doi.org/10.1007/s11556-009-0051-z

Utari, E. F. A., Kaswari, \& Yunitaningrum, W. (2015). Pengaruh Senam Lansia Terhadap Kebugaran jasmani Panti Sosial Tresna Werdha Mulia Dharma. Jurnal Pendidikan dan Pembelajaran, 4(9), 1-9.

Wardhana, B. K., \& Anwar, M. H. (2020, February). The Illustration of Physical Activity and the Elderly Physical Fitness Level. In 4th International Conference on Sport Science, Health, and Physical Education (ICSSHPE 2019) (pp. 46-49). Atlantis Press. https://doi.org/10.2991/ahsr.k.200214.013

Wijaya, N. K., Ulfiana, E., \& Wahyuni, S. D. (2020). Hubungan Karakteristik Individu, Aktivitas Fisik, dan Gaya Hidup dengan Tingkat Kebugaran Fisik pada Lansia. Indonesian Journal of Community Health Nursing, 4(2), 46. https://doi.org/10.20473/ijchn.v4i2.12365

Yusri, Y., Zulkarnain, M., \& Sitorus, R. J. (2020). Faktor Faktor yang Mempengaruhi Kebugaran Calon Jemaah Haji Kota Palembang Tahun 2019. Jurnal Epidemiologi Kesehatan Komunitas, 5(1), 57-68. https://doi.org/10.14710/jekk.v0i0.6911

Yusuf, H. (2018). Evaluasi Kebugaran Jasmani Melalui Harvard Step Testpada Mahasiswapjkr Tahun2016/2017 Ikip Budi Utomo. JP.JOK (Jurnal Pendidikan Jasmani, Olahraga dan Kesehatan), l(2), 1-13. https://doi.org/10.33503/jpjok.v1i2.162

Zelvya, P. V. A. (2014). Hubungan Status Gizi Terhadap Kebugaran Lansia di Paguyuban Senam Karang Weda Jambangan Surabaya. Jurnal Kesehatan Olahraga, 2, 1-8. 